
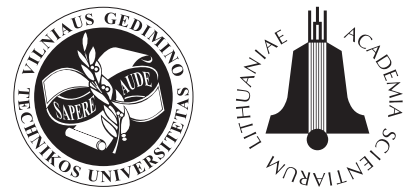

TRANSPORT

2010

25(3): 269-277

\title{
THE CALCULATION AND MEASUREMENT OF THE NATURAL FREQUENCIES OF THE BUCKET WHEEL EXCAVATOR SCHRS 1320/4X30
}

\author{
Jakub Gottvald \\ Institute of Applied Mechanics Brno, Ltd. \\ Veveři 95, 61100 Brno, Czech Republic \\ E-mail: jakub@gottvald.eu
}

Received 30 November 2009; accepted 19 July 2010

\begin{abstract}
Natural frequencies and shapes are the basic dynamic properties of each structure. On the basis of their knowledge, the sensitivity of the structure to a dynamic load could be estimated. While designing, natural frequencies are based on calculations and numerical simulations. However, computational numerical models do not exactly correspond with real structures and there are many details which have to be simplified. It means that the real natural frequencies of structures may differ from the calculated ones. It is advantageous to verify the calculated results by suitable experimental measurements in case of structures where a dynamic load dominates. The paper deals with the experimental measuring of the natural frequencies of the bucket wheel excavator SchRs 1320/4x30 and a comparison of results obtained from experimental measurements and detailed numerical simulation applying ANSYS.
\end{abstract}

Keywords: bucket wheel excavator, natural frequencies, accelerometer, modal analyses, frequency, ANSYS, measuring, Fourier transformation.

\section{Introduction}

The Institute of Applied Mechanics Brno, Ltd. in cooperation with VŠB-TU Ostrava and Prodeco a.s. are the solvers of project No FT-TA4/018 'Moderní trendy zvyšování spolehlivosti zařizení pro povrchovou těžbu užitkových nerostù' ('Modern Trends in Increasing Equipment Reliability for the Open-Cast Mining of Utility Minerals') (Gottvald 2009a; Gottvald et al. 2009). The possibilities of increasing the reliability, efficiency and lifespan of the steel structure of digging equipment are investigated in this project.

It was agreed that research would be primarily focused on the bucket wheel excavator SchRs 1320 actually working at open coal mine Nástup Tušimice, the Czech Republic. The determination of natural frequencies was an important part of the project.

The soil crusher was installed on the bucket wheel excavator by the end of the year 2008. The crusher was installed on the end of the bucket-wheel boom between the wheel and conveyor. The weight of the installed crusher is approximately 44.5 tons. For maintaining the stability of the machine, counterweight had to be increased by about 53 tons, so the total weight increased by 100 tons. The calculations of the natural frequencies of the excavator model before installing the crusher were described in previous works (Gottvald 2008a, 2008b).
The experts of IAM Brno wanted to verify computed natural frequencies by experimental measurements conducted directly on the excavator. There was no possibility of conducting the experiment before the installation of the crusher, thus the experiment was carried out in July 2009. It meant that the crusher had to be taken into consideration.

Four trials were made during the experiment. Three trials were conducted when the wheel's buckets did not bear the working face i.e. vibrations from the whole top structures of the excavator were not prevented. The last trial was carried out for the buckets bearing the working face. The aim of these two different approaches was to determine changes (and their significance) in natural frequencies, though mainly it was focused on determining the value of the damping ratio. Determining natural frequencies was based on processing the signals measuring the responses of excavator steel structure to shock load. A shock impulse on structures was made by shooting the hanging rope of 26.4 ton weight which was attached to the wheel boom. 28 accelerometers were in progress during the experiment. The accelerometers were installed on important parts of the top structures of the excavator.

Interference frequencies not caused by mechanical vibrations from steel structure were induced, so the 
unwanted frequencies were smoothed out. Afterwards, signals were oriented to the right coordinate system because not all accelerometers could be installed in the right direction. Finally, frequency spectrum was calculated using the Fourier transform.

The presented paper deals with the experimental measurement of the natural frequencies of the bucket wheel excavator SchRs 1320/4x30 and a comparison of experimental results with those obtained from the detailed numerical simulation using ANSYS (Element Reference... 2007; Theory Reference for ANSYS... 2007).

\section{Bucket Wheel Excavator SchRs 1320/4x30}

The bucket wheel excavator SchRs 1320/4x30 is an excavator with a non telescopic wheel boom. The theoretical capacity of the excavator is 5500 cubic meters of soil. The diameter of the bucket wheel is 12.5 meters and the rotation speed of the wheel is $5.58 \mathrm{rpm}$ on $100 \%$ power. The bucket wheel excavator is about 60 meters high and weights 4193 tons. The weights of the excavator components are as follows: loading unit - 570 tons, an intermediate bridge - 409 tons and the netto weight of the excavator - 3114.5 tons. An actual location is Nástup Tušimice in the Czech Republic

The bucket wheel excavator SchRs 1320/4x30 was put in commission in 2006. The general contractor was Prodeco a.s. in cooperation with TryssenKrupp which designed the excavator and supplied some of its parts.

An overall view of the excavator is presented in Fig. 1.

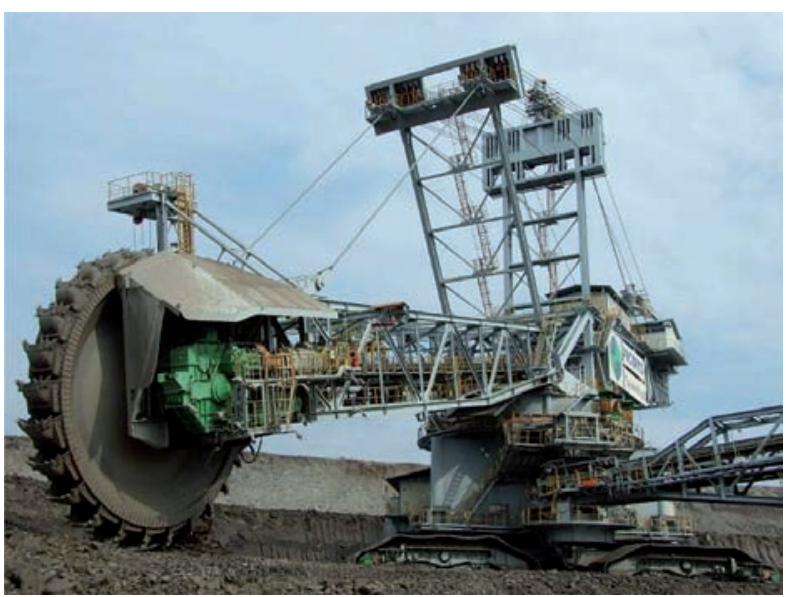

Fig. 1. Bucket wheel excavator SchRs 1320/4x30

\section{Measuring Natural Frequencies}

The frequency spectrum of the natural frequencies of the bucket wheel excavator was calculated applying program FlexPro 7 (2007) employed by Weisang Company using the Fourier transform. Signals were obtained by measuring the response of excavator steel structure to shock load. As mentioned above, the shock impulse on the structures was made shooting the hanging rope of 26.4 tons in weight. The load was hanged on the wheel boom on the first framework joint over the bucket wheel, see Fig. 2 for details. Rope shooting was made by industrial plastic explosive Semtex 1A 21/300 and electric detonators Dem S.

28 acceleration types of B3 produced by Seika.de Company were in progress during the measurement. They were attached in triplets to the top steel structure of the excavator. Each triplet was able to log up signals at all three directions of oscillation. A throat impulse was made in vertical direction. The location of sensors triplets is marked by a blue colour (sensor code) in Fig. 3.

a)

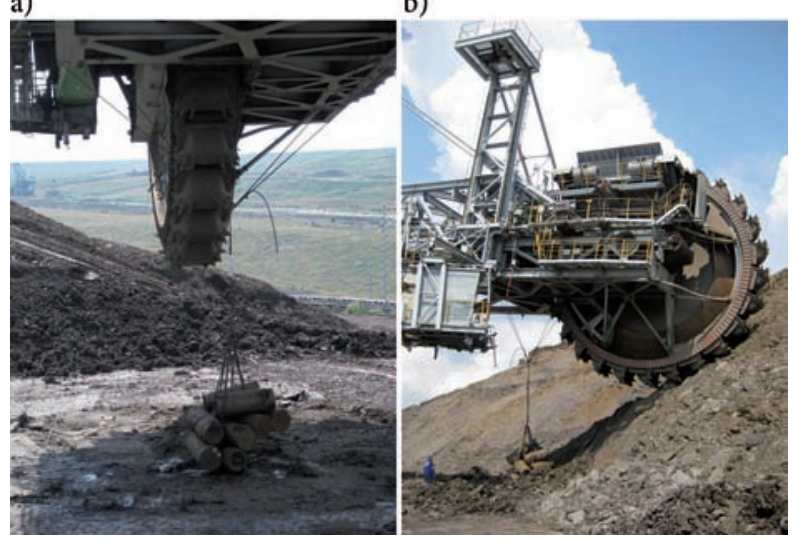

Fig. 2. Installation of the hanging rope

The experiment involved four trials three of which were made when wheel's buckets did not bear the working face, i.e. vibrations from the whole top structures of the excavator were not prevented. For details see Fig. $2 \mathrm{a}$. The last trial was made when the buckets bear the working face. For details see Fig. 2b. The aim of these two different approaches was to determine changes (and their significance) in natural frequencies but mainly it was focused on determining the value of the damping ratio.

The signals were measured by the sampling frequency of $800 \mathrm{~Hz}$. Each trial was measured and saved in a separate file copied immediately from measuring a device to a laptop. The time axis of measurement devices connected by Ethernet cable was synchronized before each trial.

Picture sequences of the experiment are shown in Figs 4 and 5.

In the measured signal interference, frequencies not caused by mechanical vibrations from steel structure were induced. They were mainly various electrical signal noises, induced a frequency of $50 \mathrm{~Hz}$ from the electrical network, etc. This problem can be partially prevented by using shielded cables; however, it could not be avoided totally. The unwanted frequencies were filtered out from raw signals. The main natural frequencies of the bucket wheel excavators of the same type as SchRs 1320 are very low. First natural frequencies are those of $1 \mathrm{~Hz}$. Thus, we can filter out all frequencies over $20 \mathrm{~Hz}$. These frequencies are of different origin than those of the oscil- 


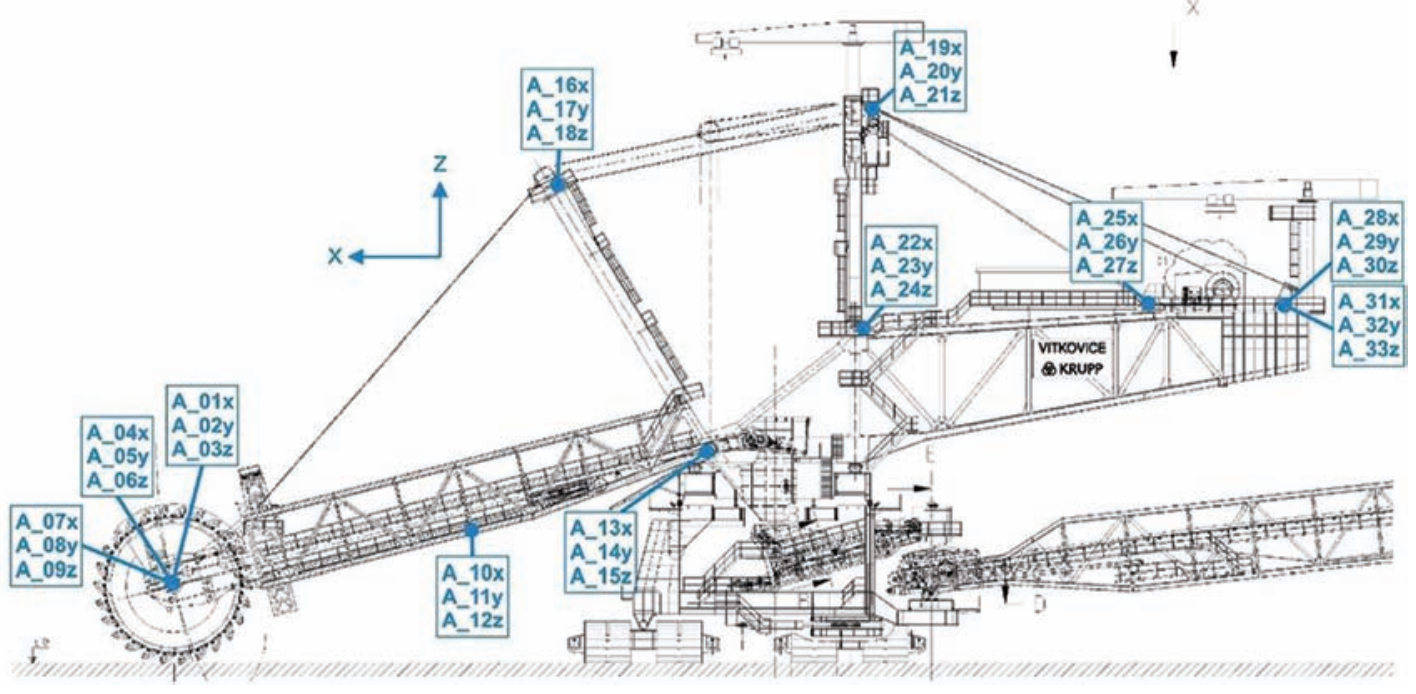

Fig. 3. The positions of sensors of the excavator
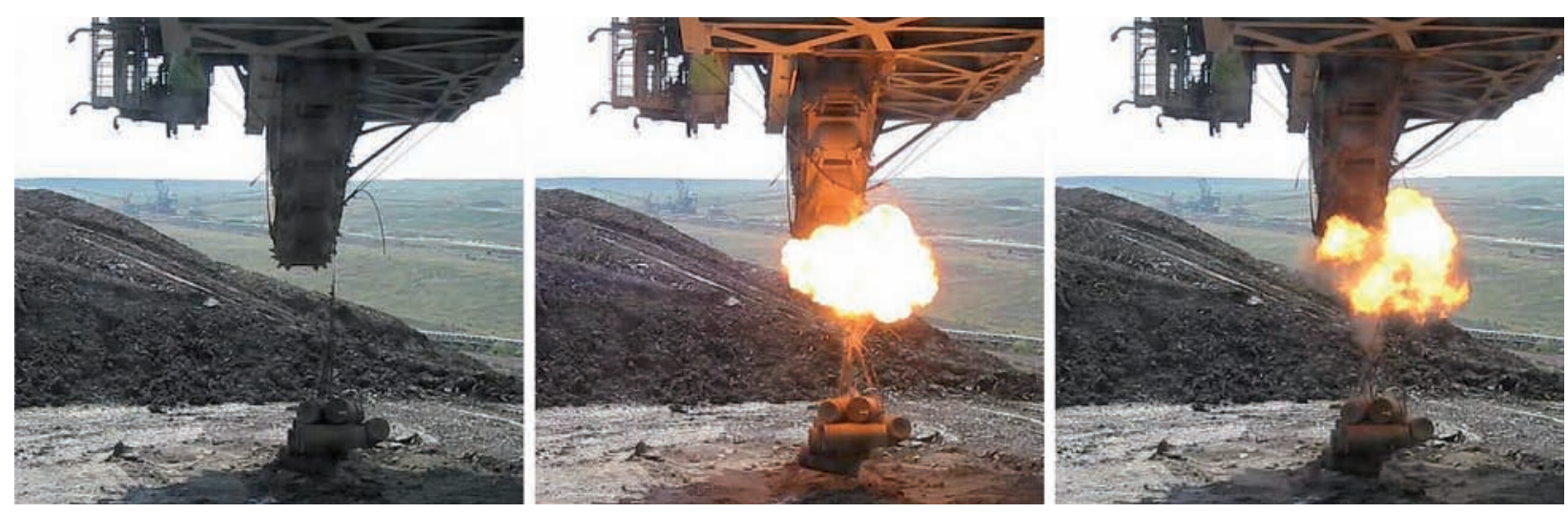

Fig. 4. Shooting the hanging rope
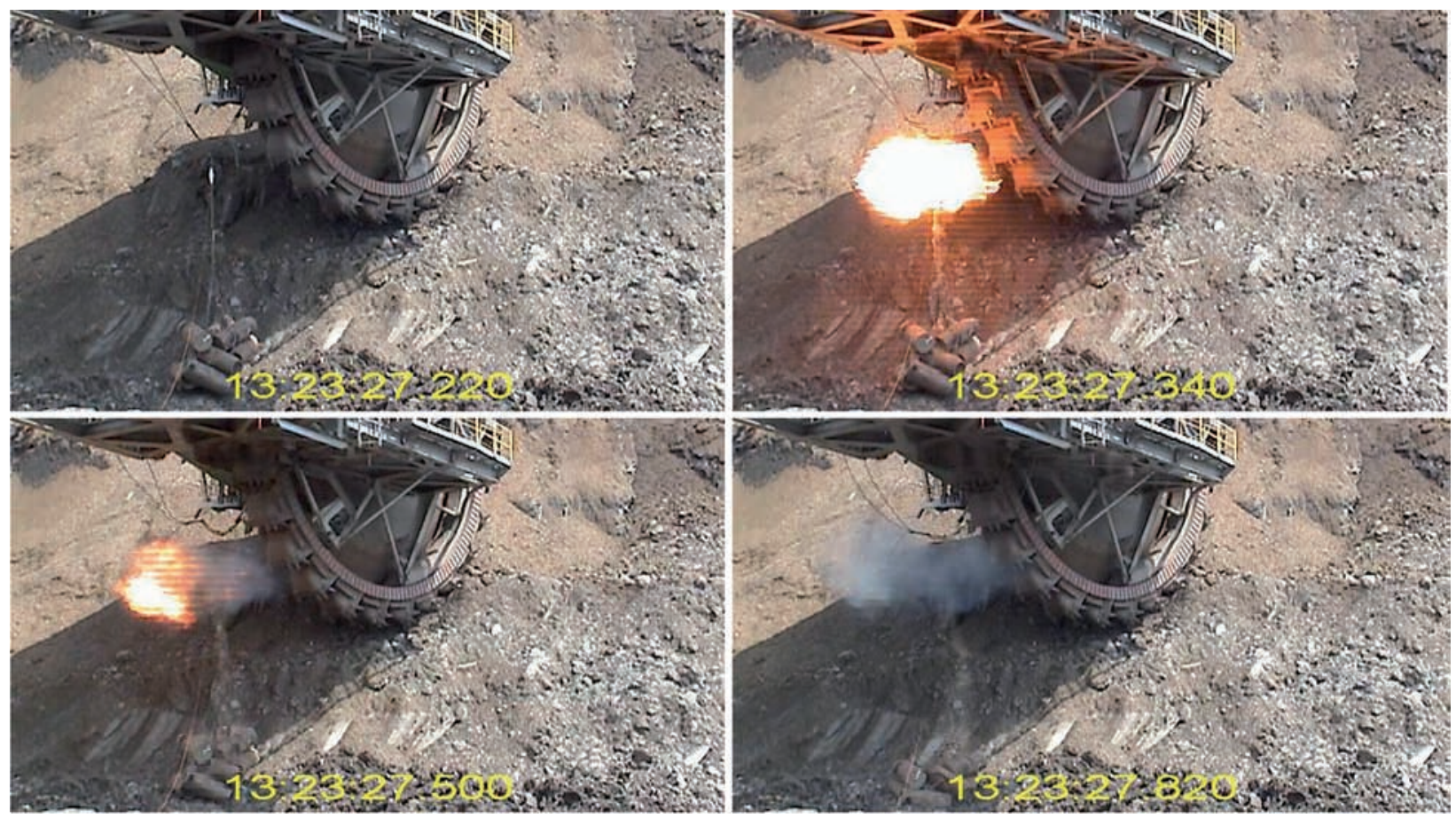

Fig. 5. Overshooting the hanging rope 
lation of the steel structure of the excavator. For cleaning up signals, FIR filter (Finite Impulse Response Filter) and Chebyshev window were used. X-axis position was moved to the steady state in the filtered signals. In the next step, the signals were oriented to the right coordinate system because not all accelerometers could be installed in the right direction during the measurement.

A section of 25 seconds long recording the oscillation of the excavator directly after shooting the rope was isolated from the measured signals. The signals from accelerometers A_01x, A_02y and A_03z are plotted in Figs 6 and 7. Fig. 6 shows the already filtered record of the signals measured while the buckets did not bear the working face. Fig. 7 shows the plotted signals measured when the buckets bore the working face and the signals are also already filtered. At first sight, it is evident that oscillation with the supported bucked wheel is more dumped. The proportional damping of steel structure for both cases was calculated in the final report on measurement (Gottvald 2009a). The formulas published by (Brepta, Průst and Turek 1994) were used. In the first case (unsupported bucked wheel), proportional damping is $0.8 \%$ while in the second one it makes $7.8 \%$.

The first natural frequency was $0.56 \mathrm{~Hz}$ when the buckets did not bear the working face. This frequency is the most important because of swinging the upper part of the steel structures of the excavator. The measurement of the buckets bearing the working face shows that the value of the first natural frequency was increased to $0.6 \mathrm{~Hz}$. The other located frequencies are noted in Table 1 or in more details in (Gottvald 2009a). The table is listing the values of frequencies, the direction of oscillation and the parts of the excavator where the frequencies were measured.

\section{Modal Analysis Using Finite Element Method (FEM) Program ANSYS}

\subsection{Description of the FEM Model of the Excavator}

The soil crusher was installed on the bucket wheel excavator by the end of the year 2008 which allowed increasing the weight of the excavator. The crusher was installed on the end of the bucket wheel boom between the wheel and conveyor. The weight of the installed crusher is approximately 44.5 tons. For maintaining the stability of the machine, counterweight had to be increased by about 53 tons, so that the total weight increased by 100 tons. Changes in the end of the bucket wheel boom are presented in Fig. 8. The changed situation caused that the model of the excavator presented in (Gottvald 2008a, 2008b) had to be edited.

Calculations of the natural frequencies of the excavator model before the installation of crushers were described in the previous author's works (Gottvald 2009b, 2009c, 2008a, 2008b). The experts of the IAM Brno wanted to verify computed natural frequencies by experimental measurements carried out directly on the excavator. There was no possibility of conducting the experiment before the installation of the crusher, so the experiment was performed in July 2009 which meant that the crusher had to be taken into consideration.

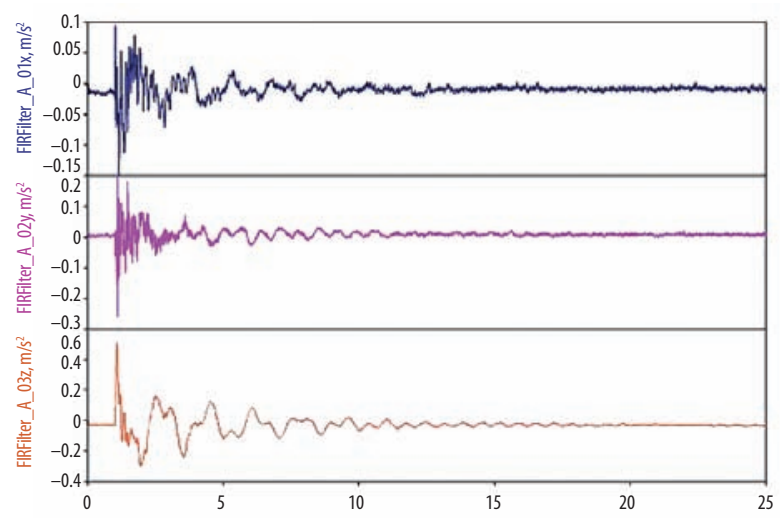

Fig. 7. The filtered signal - supported bucked wheel

Fig. 6. The filtered signal - unsupported bucked wheel

Table 1. Measured natural frequencies

\begin{tabular}{cccccc}
\hline & \multicolumn{2}{c}{ Unsupported wheel boom } & \multicolumn{3}{c}{ Supported wheel boom } \\
\hline Frequency, Hz & Axes & Place of localization & Frequency, Hz & Axes & Place of localization \\
\hline 0.56 & $\mathrm{x}, \mathrm{y}, \mathrm{z}$ & whole excavator & 0.60 & $\mathrm{x}, \mathrm{y}, \mathrm{z}$ & whole excavator \\
\hline 0.88 & $\mathrm{y}$ & whole excavator & 0.84 & $\mathrm{y}$ & counterweiqht \\
\hline 1.36 & $\mathrm{x}, \mathrm{y}, \mathrm{z}$ & whole excavator & 0.96 & $\mathrm{y}$ & wheel boom \\
\hline 1.6 & $\mathrm{y}$ & both masts & 1.40 & $\mathrm{x}, \mathrm{y}, \mathrm{z}$ & whole excavator \\
\hline 1.76 & $\mathrm{y}$ & both masts & 1.92 & $\mathrm{y}$ & Masts, wheel boom \\
\hline 1.96 & $\mathrm{y}$ & Masts, wheel boom & & $\mathrm{y}$ & \\
\hline
\end{tabular}


Changes in the end of the bucket wheel boom are presented in Fig. 8. The made changes caused a need for editing the model of the excavator presented in (Gottvald 2008a, 2008b).

The FEM model of the bucket wheel excavator 1320 was created using program ANSYS. The model was produced in a proper way, see Figs 9-11. The excavator was modelled without an intermediate bridge and loading unit. The computational model was created using beam elements BEAM44 and LINK10, shell elements SHELL43 and volume elements SOLID45. The model with the crusher consists of 206247 elements located in 197105 nodes. The model is presented in Fig. 11. Changes near the bucket wheel are shown in Figs 9 and 10.

The model of the excavator was made very precisely, mostly using shell elements. During the process of creating the model, special attention was paid to modelling the proper behaviour of joints. More than 20 different examples of shell element thickness are defined in the model. The beam element was used for modelling the types of reinforcements or small beam parts e. g. construction of operator's cabin. The total number of defined profiles is 75 . Ropes were modelled applying element type LINK10. The diameter of the fixed ropes between mast and booms is $124 \mathrm{~mm}$, whereas the diameter of other ropes is $56 \mathrm{~mm}$. The equipment of the machinery room, gear-box and shaft of bucket wheel counterweight etc. were modelled with solid elements. The geometry of excavators was taken from approximately 200 drawings.

The weight of the excavator was controlled and compared with updated stability calculation. Not only weight was checked but also the centre of gravity mainly of the upper truss part of the excavator was fine-tuned. The gravity centre of the model was also taken from the calculation of updated stability. The model is presented in Fig. 11. a)

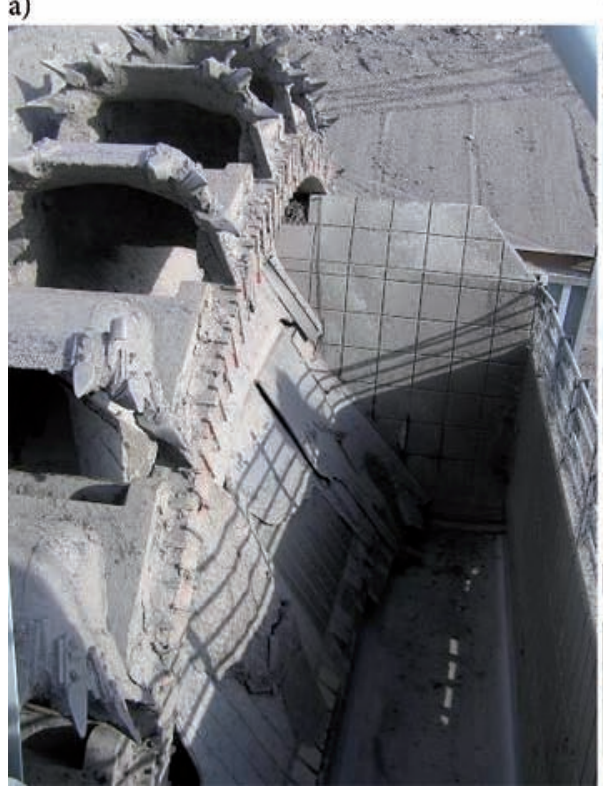

b)

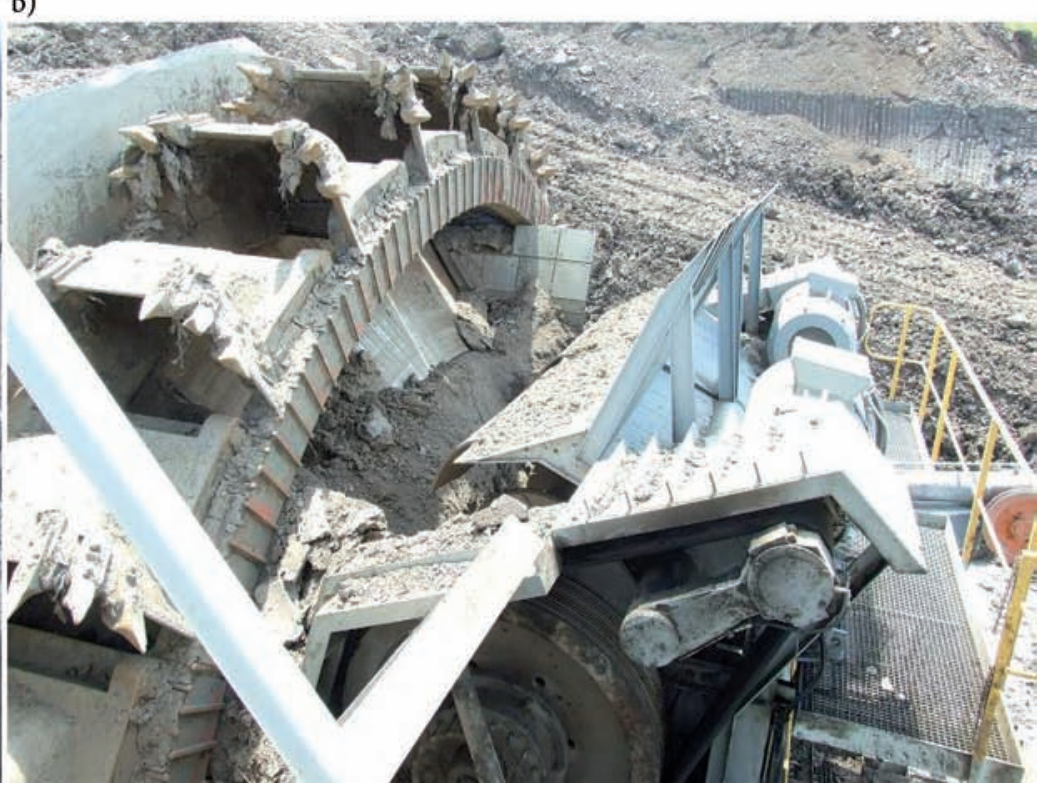

Fig. 8. The bucket wheel: a - without the crusher b - with the crusher

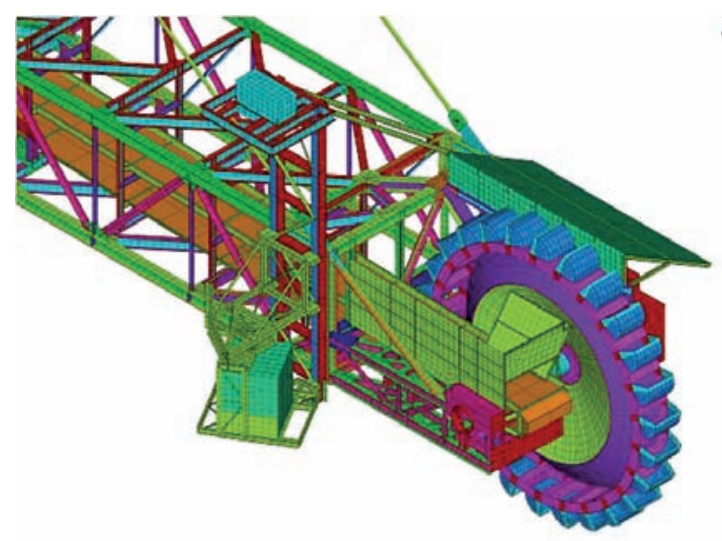

$\mathbf{N}$

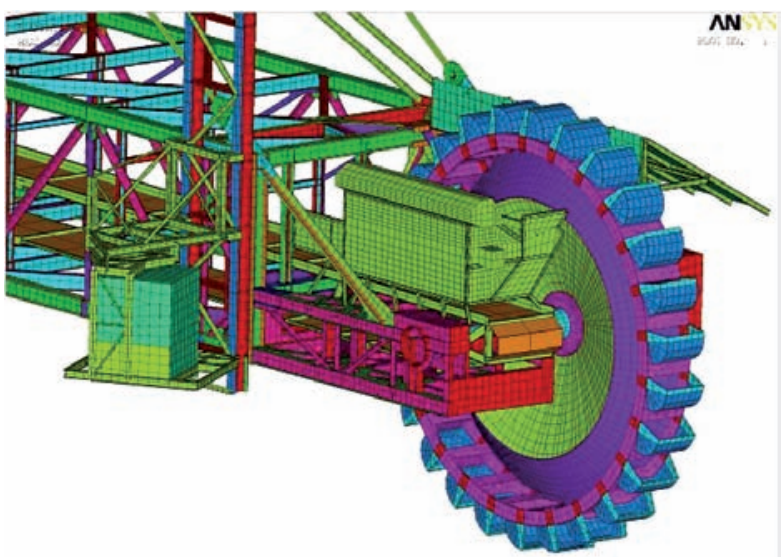

Fig. 9. The model of the bucket wheel without the crusher

Fig. 10. The model of the bucket wheel with the crusher 


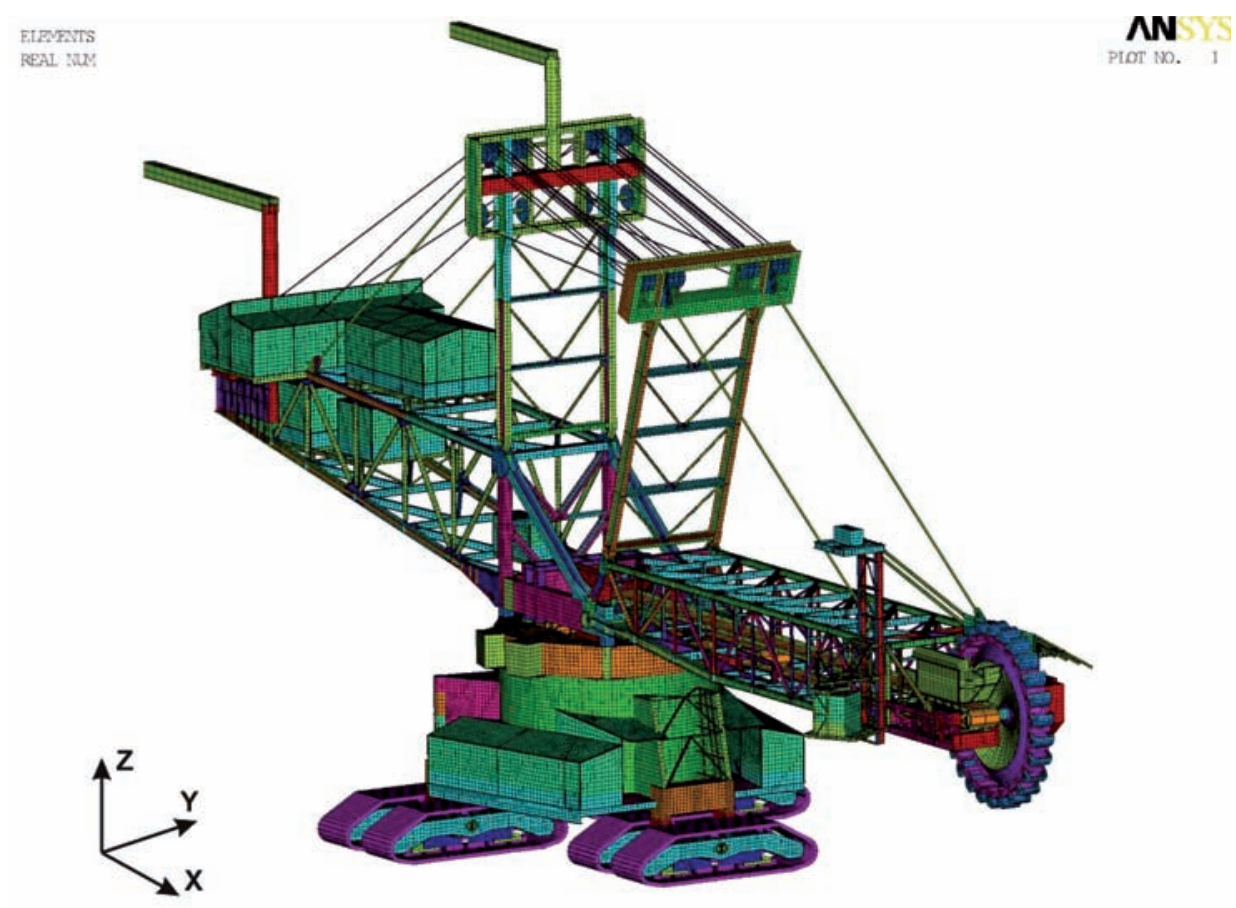

Fig. 11. The model of the bucket wheel excavator

\subsection{Computing Natural Frequencies}

Modal analyses are the basis for all simulations of structural dynamics. On the basis of knowledge of natural frequencies and the shape sensitivity of the structure to a dynamic load could be estimated. The significance of an individual shape and corresponding natural frequency is given by the so-called effective modal mass. The mass of the effective modal is equalled to the mass that oscillates at each natural frequency. For the modal analysis of the bucket wheel excavator 1320, the first fifty frequencies up to approximately $6 \mathrm{~Hz}$ were computed using the Block Lanczos method. The range of analysis was adequate because these types of the bucket wheel excavator have the first natural frequency making up to $1 \mathrm{~Hz}$. The selected natural frequencies are plotted in
Table 2 where the coefficients of direction significance are noted (Element Reference... 2007; Theory Reference for ANSYS... 2007).

The most dominant frequency is the first natural frequency that equals $0.543 \mathrm{~Hz}$. It is a rotating mode shape received when the upper truss part of the excavator is swinging. In the previous studies (Gottvald 2008a, $2008 \mathrm{~b}$ ), the first natural frequency was $0.572 \mathrm{~Hz}$ and was caused by analysing the excavator without the added mass of the crusher and counterweight.

\section{Comparison of Computed and Measured Natural Frequencies}

The modal analysis of the wheel buckets not bearing the working face was made applying program ANSYS, so a

Table 2. Selected natural frequencies

\begin{tabular}{|c|c|c|c|c|c|c|c|}
\hline Mode & Frequency & X Direction & Y Direction & Z Direction & Rotation X & Rotation $\mathrm{Y}$ & Rotation Z \\
\hline 1 & 0.543 & 0.21 & 0.00 & 0.31 & 0.00 & 1.00 & 0.01 \\
\hline 2 & 0.598 & 0.00 & 0.09 & 0.00 & 0.12 & 0.01 & 1.00 \\
\hline 3 & 0.854 & 0.00 & 1.00 & 0.00 & 1.00 & 0.00 & 0.02 \\
\hline 4 & 1.026 & 0.01 & 0.89 & 0.02 & 0.89 & 0.01 & 0.13 \\
\hline 5 & 1.039 & 0.09 & 0.03 & 0.41 & 0.03 & 0.12 & 0.00 \\
\hline 6 & 1.125 & 0.00 & 0.13 & 0.00 & 0.48 & 0.00 & 0.01 \\
\hline 7 & 1.415 & 0.25 & 0.01 & 1.00 & 0.01 & 0.35 & 0.00 \\
\hline 8 & 1.528 & 0.00 & 0.31 & 0.01 & 0.55 & 0.00 & 0.02 \\
\hline 9 & 1.574 & 0.08 & 0.00 & 0.27 & 0.01 & 0.11 & 0.00 \\
\hline 10 & 1.646 & 0.01 & 0.10 & 0.03 & 0.26 & 0.01 & 0.08 \\
\hline 11 & 1.956 & 0.00 & 0.14 & 0.07 & 0.05 & 0.01 & 0.02 \\
\hline 12 & 2.649 & 0.00 & 0.08 & 0.00 & 0.03 & 0.00 & 0.00 \\
\hline 13 & 2.806 & 0.16 & 0.06 & 0.07 & 0.04 & 0.06 & 0.01 \\
\hline 14 & 2.845 & 1.00 & 0.00 & 0.27 & 0.01 & 0.38 & 0.00 \\
\hline 26 & 4.155 & 0.00 & 0.38 & 0.01 & 0.19 & 0.00 & 0.00 \\
\hline 29 & 4.292 & 0.22 & 0.04 & 0.04 & 0.02 & 0.10 & 0.01 \\
\hline 33 & 4.576 & 0.02 & 0.44 & 0.01 & 0.24 & 0.01 & 0.05 \\
\hline
\end{tabular}


comparison could be made. The comparison of results is made graphically and shown in Figs 12 and 13. The results measured at the end of the wheel boom are dis- played in Fig. 12. Fig. 13 indicates the results of rigid mast (mast jointed with wheel boom). Computed (blue) and measured (red) magnitudes of frequencies are noted.

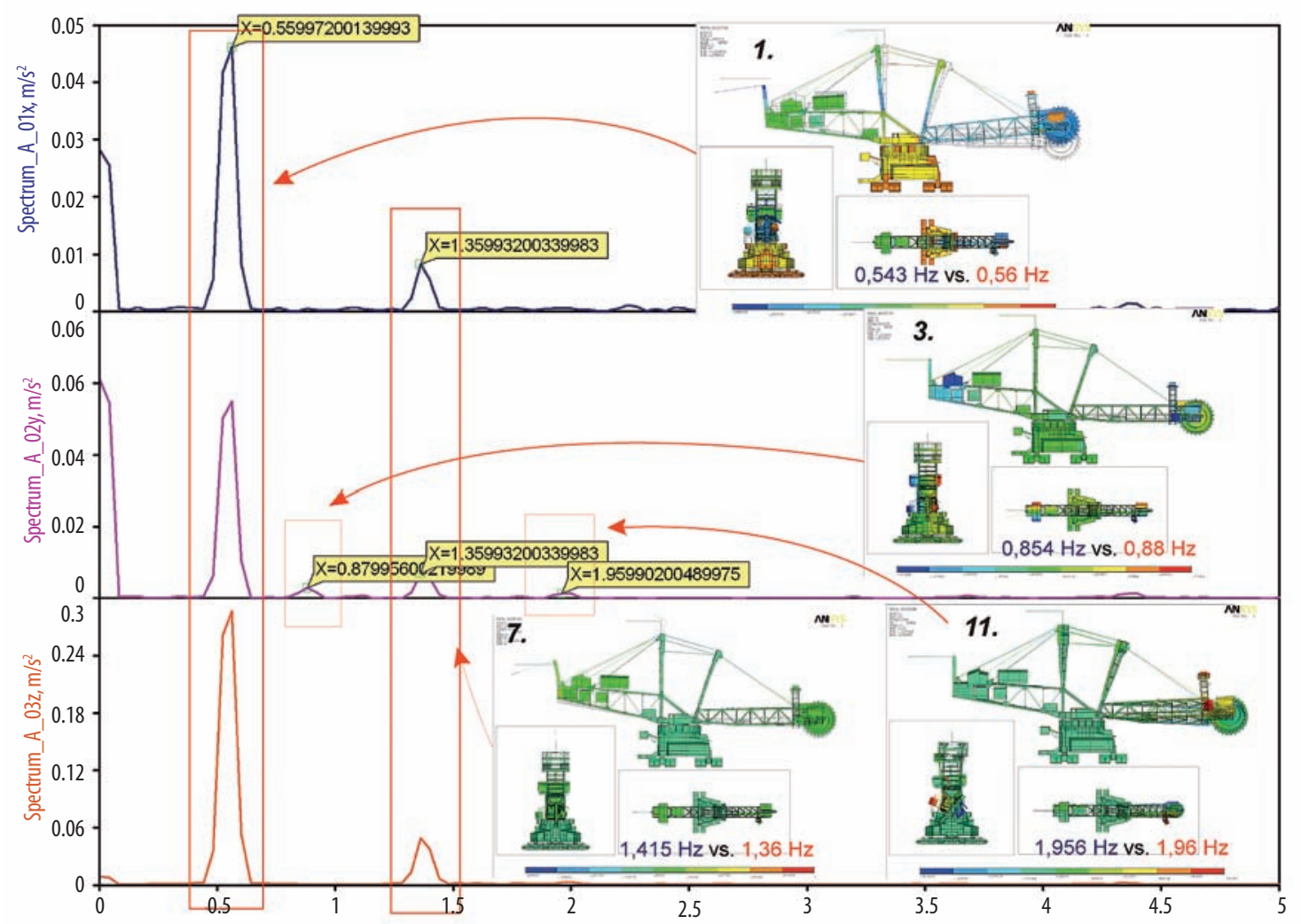

Fig. 12. A comparison of results - the end of the wheel boom

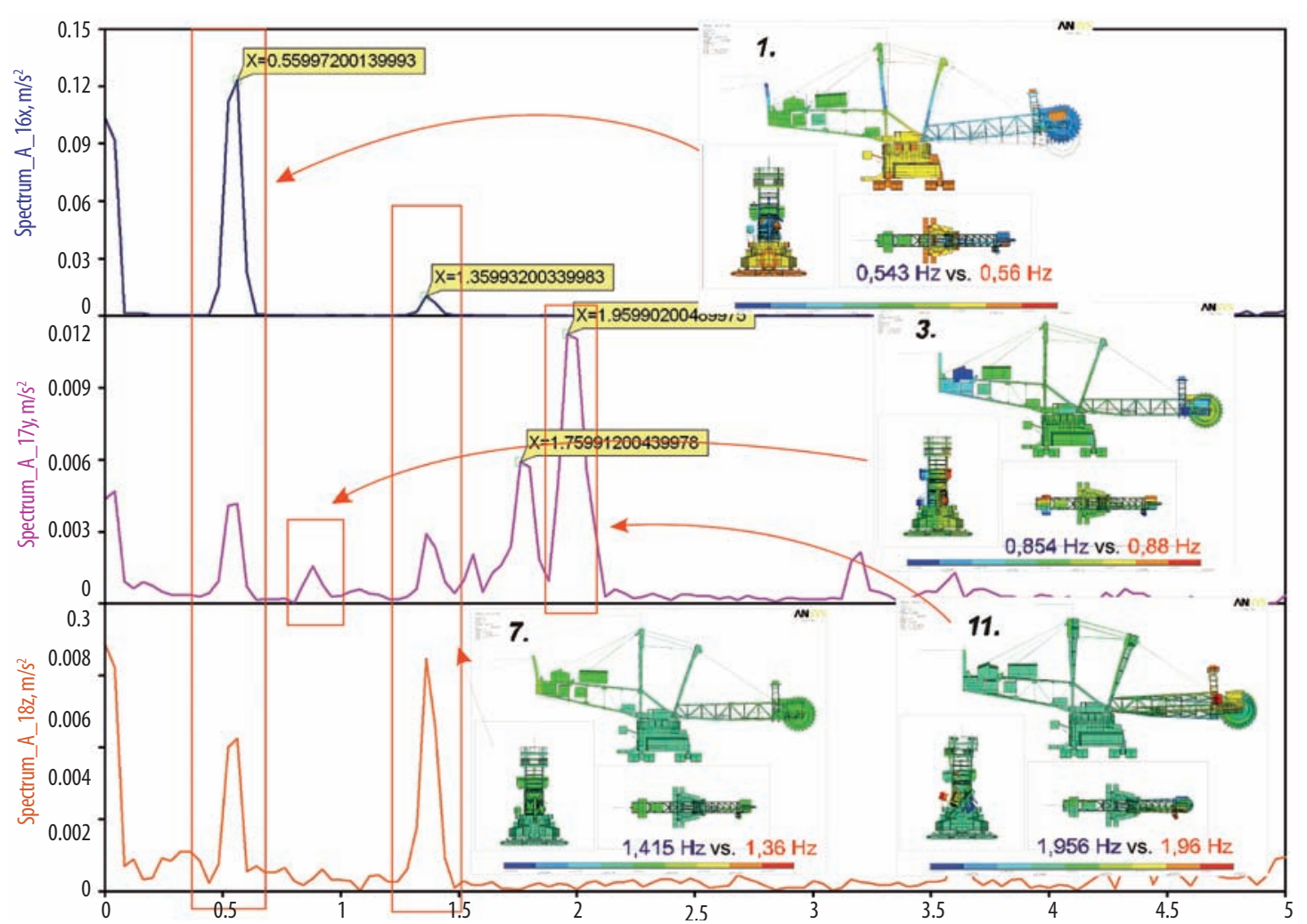

Fig. 13. A comparison of results - rigid mast 


\section{Conclusions}

On the basis of the comparison between measured and computed results, the following points could be presented:

- the value of the measured first natural frequency is $0.56 \mathrm{~Hz}$. A signal of 25 second long was evaluated;

- the value of the computed first natural frequency is $0.543 \mathrm{~Hz}$;

- when a longer signal is evaluated, e.g. $230 \mathrm{sec}-$ onds (Gottvald 2009a, 2009c), the value of the first natural frequency is $0.545 \mathrm{~Hz}$ (also computed by FFT analyses). This value is practically identical with the one computed by ANSYS;

- in previous works where natural frequencies were calculated without the crusher (Gottvald 2008a, 2008b), the first natural frequency made $0.572 \mathrm{~Hz}$.

A comparison of experimental results with those obtained by means of the FEM model shows that the FEM model very accurately understands the behaviour of real structure. Dominant excitation forces stressing the structure are the dynamic load actions of a generally random character. A stochastic sensitivity analysis of the dynamic response of the structure will be therefore elaborated by means of a theoretical model.

In the context of modelling, sensitivity analysis means very different things to different people, see, e. g., (Mang et al. 2009; Chow and Chow 2009). The basic stochastic sensitivity analysis methods of structure response were published, e. g. (Kala 2007, 2009); related knowledge (Kala et al. 2009) can also be applied for making a solution. The procedure following the correlation between input and output is one of the most practical and frequently applied methods are very appropriate for nonlinear finite element models, see e.g. (Melcher et al. 2009). The FEM model presented here belongs to computer time demanding models.

Sensitivity analysis provides us with information on the quantities that must be considered paying and concentrating attention in the future controlling activities following failures in the structure. By means of the results presented in this paper and on behalf of sensitivity analysis, it will be possible to identify dominant quantities taking the maximum part in fatigue failures and decreasing the life time of the structure.

\section{Acknowledgements}

The author gratefully acknowledges the partial support provided by the Czech Science Foundation within the project of GACR No.103/08/0275 and support provided by the Czech Ministry of Industry and Trade within the project FT-TA4/018.

\section{References}

Brepta, R.; Půst, L.; Turek, F. 1994. Mechanické kmitání TP 71 [Mechanical vibrations TP 71]. Praha: Sobotáles. 589 p.

Chow, C. L.; Chow. W. K. 2009. Fire safety aspects of refuge floors in supertall buildings with computational fluid dynamics, Journal of Civil Engineering and Management 15(3): 225-236. doi:10.3846/1392-3730.2009.15.225-236

Element Reference, ANSYS Release 11.0. 2007. ANSYS, Inc.

FlexPro 7: Program Manual. 2007. Weisang GbmH.

Gottvald, J. 2008a. Výpočet dynamických vlastností kolesového rypadla SchRs 1320/4x30 [Computation of dynamic characteristic of the bucket wheel excavator SchRs 1320/4x30], in ANSYS Konference 2008 [ANSYS Conference 2008], 8 p. [CD].

Gottvald, J. 2008b. Výpočet vlastních frekvencí kolesového rypadla SchRs 1320/4x30 v různých pracovních pozicích [Computation of natural frequencies of the bucket wheel excavator SchRs 1320/4x30 in various operating positions], in Problémy provozu, údržby a oprav strojních zařizení [Problems of Operation, Maintenance and Repair of Machinery], 15 p. [CD]

Gottvald, J. 2009a. Výzkumná zpráva projektu moderní trendy zvyšováni spolehlivosti zařizení pro povrchovou těžbu užitkových nerostů, Etapa 6b: Ověrení metodik in-situ a návrh na jejich uplatněn - Měrení vlastních frekvencí kolesového rypadla SchRs 1320 [FT-TA4/018 Modern Trends in Increasing Equipment Reliability for the Open-Cast Mining of Utility Minerals, Part 6b: In-Situ Verification of Methods and a Proposal for Their Application - Measure of Natural Frequencies of the Bucket Wheel Excavator SchRs 1320. Research Report]. 59 p.

Gottvald, J. 2009b. Problematika dynamiky kolesového rypadla SchRs 1320/4x30 [Problems of dynamics of the bucket wheel excavator SchRs 1320/4x30], in 11. odborná konference doktorského studia JUNIORSTAV 2009 [11th Professional Conference of Postgraduate Students JUNIORSTAV 2009], 8 p. [CD].

Gottvald, J. 2009c. Porovnání vypočtených a naměřených vlastních frekvencí kolesového rypadla SchRs 1320 [Comparison of measured and computed natural frequencies of bucket wheel excavator SchRs 1320], in ANSYS Konference 2009 [ANSYS Conference 2009], 8 p. [CD].

Gottvald, J.; Krása, J.; Helebrant, F.; Fries, F.; Kraus, V. 2009. Výzkumná zpráva projektu moderní trendy zvyšování spolehlivosti zařizení pro povrchovou těžbu užitkových nerostů, Etapa 6b: Ověrení metodik in-situ a návrh na jejich uplatnění - Návrh měrení [FT-TA4/018 Modern Trends in Increasing Equipment Reliability for the Open-Cast Mining of Utility Minerals, Part 6b: In-Situ Verification of Methods and a Proposal for Their Application - Draft Methodology for Measuring. Research Report]. 22 p.

Kala, Z. 2007. Stability problems of steel structures in the presence of stochastic and fuzzy uncertainty, Thin-Walled Structures 45(10-11): 861-865. doi:10.1016/j.tws.2007.08.007

Kala, Z. 2009. Sensitivity assessment of steel members under compression, Engineering Structures 31(6): 1344-1348. doi:10.1016/j.engstruct.2008.04.001 
Kala, Z.; Melcher, J.; Puklický, L. 2009. Material and geometrical characteristics of structural steels based on statistical analysis of metallurgical products, Journal of Civil Engineering and Management 15(3): 299-307.

doi:10.3846/1392-3730.2009.15.299-307

Mang, H. A.; Jia, X.; Hoefinger, G. 2009. Hilltop buckling as the $A$ and $\Omega$ in sensitivity analysis of the initial postbuckling behavior of elastic structures, Journal of Civil Engineering and Management 15(1): 35-46. doi:10.3846/1392-3730.2009.15.35-46

Melcher, J.; Škaloud, M.; Kala, Z.; Karmazínová, M. 2009. Sensitivity and statistical analysis within the elaboration of steel plated girder resistance, Advanced Steel Construction 5(2): 120-126.

Theory Reference for ANSYS and ANSYS Workbench 11.0, ANSYS Release 11.0. 2007. ANSYS, Inc. 